\title{
The Rhizopus oryzae secreted aspartic proteinase gene family: an analysis of gene expression
}

\author{
Peter C. Farley't and Patrick A. Sullivan ${ }^{2}$ \\ Author for correspondence: Peter C. Farley. Tel: +64 6350 6249. Fax: +64 63505688. \\ e-mail: P.C.Farley@massey.ac.nz
}

1 Department of Biochemistry, Otago University, Dunedin, New Zealand

2 Institute of Molecular Biosciences, Massey University, Private Bag 11-222, Palmerston North, New Zealand

\begin{abstract}
Rhizopus oryzae was shown to possess a secreted aspartic proteinase gene family (sap) of at least four members (sap1-sap4). Within the family there was $77-87 \%$ identity at the nucleotide level and 76-92\% identity at the amino acid level. Transcription of three members of this gene family (sap1-sap3) required an acidic medium ( $\mathrm{pH}<4.5)$ and either nitrogen or sulphur derepression. Regulation was co-ordinate and hierarchical, with pH occupying the higher position in the hierarchy. Exogenous protein increased transcript levels, probably via the provision of metabolic intermediates rather than by direct induction of gene expression. sap4 was not expressed under these conditions. SAP1-SAP4 are predicted to have almost identical substrate-binding sites and therefore substrate specificity. It is proposed that sap1-sap3 exist to provide amplified expression of the secreted aspartic proteinase because protein, an important secondary nitrogen source for this fungus, requires extensive degradation to make its nitrogen available to the cell.
\end{abstract}

Keywords: Rhizopus oryzae, filamentous fungi, sulphur metabolism, nitrogen metabolism, secreted aspartic proteinase

\section{INTRODUCTION}

Rhizopus oryzae, a filamentous fungus which is ubiquitous in soil (Webster, 1980), is also medically and economically important. It is the most frequent aetiological agent of zygomycosis (Frye \& Reinhardt, 1993; Espinel-Ingroff et al., 1987; Bouchara et al., 1996), and it is used in a solid-substrate fermentation to produce tempe from soya beans (Nout $\&$ Rombouts, 1990) and in industrial fermentations for the production of glucoamylase (Radford et al., 1996) and fumaric acid (Friedberg et al., 1995; Longacre et al., 1997). R. oryzae secretes aspartic proteinases which are critical to the production of good quality tempe (Wang \& Hesseltine, 1965; Lim et al., 1987) and, by analogy with other pathogenic fungi, might contribute to the virulence of the organism (Fallon et al., 1997).

\footnotetext{
†Present address: Institute of Molecular Biosciences, Massey University, Private Bag 11-222, Palmerston North, New Zealand

Abbreviation: SAP, secreted aspartic proteinase.

The GenBank accession numbers for the sequences reported in this paper are: AF026128 (sap1), AF026129 (sap2), AF026130 (sap3), AF026131 (sap4) and AF026127 (rpys18).
}

Proteolytic enzymes are secreted by a variety of fungi. Where they have been studied, these enzymes are often found to be the product of a single-copy gene; for example, the aspartic proteinases secreted by Glomerella cingulata (Clark et al., 1997), Aspergillus oryzae (Berka et al., 1993) and Aspergillus awamori (Berka et al., 1990), and the serine proteinase secreted by Aspergillus niger (Jarai et al., 1994). However, the proteinases secreted by Rhizopus spp., Candida spp. (best studied in C. albicans) (Monod et al., 1994) and Tritirachium album (Samai et al., 1989, 1990) are the products of multigene families.

The C. albicans secreted aspartic proteinase (SAP) gene family comprises at least seven members which show $32-91 \%$ identity in the amino acid sequence of the mature proteins. This family comprises three distinct groups: SAP1-SAP3 $(70-74 \%$ identity within the group), SAP4-SAP6 (75-91\% identity within the group) and SAP7 (possibly a pseudogene). The T. album secreted serine proteinase gene family comprises at least two members (those encoding proteinase $T$ and proteinase $\mathrm{R}$ ) which show $54 \%$ identity in the amino acid sequences of the proteins. The gene encoding proteinase $\mathrm{K}$, which is secreted by a different strain of $T$. album (Gunkel \& Gassen, 1989), belongs to this family. 
Rhizopus SAPs (the rhizopuspepsins) have been studied, not only in $R$. oryzae, but also in Rhizopus chinensis and Rhizopus niveus. Five isoenzymes are known to be secreted by $R$. chinensis (Ohtsuru et al., 1982) and five genes encoding SAPs have been identified in $R$. niveus (Horiuchi et al., 1988; Sakaguchi et al., 1992), which show $72-90 \%$ identity in their predicted amino acid sequences. In addition, the cDNA for one of the $R$. chinensis enzymes has been sequenced (Delaney et al., 1987). The amino acid sequence of two of the $R$. chinensis enzymes has been determined (Takahashi, 1988), showing that more than $97 \%$ of the residues are identical, and the three-dimensional structure of one of them has been solved (Suguna et al., 1987).

Proteinases typically have an extended substrate-binding site (Barrett, 1994). Structural studies have allowed the amino acid residues which define the extended substratebinding site to be defined for both the $R$. chinensis and C. albicans SAPs and for proteinase K. Proteinase K has broad substrate specificity (Betzel et al., 1988, 1993) and because its substrate-recognition site is defined by two strands of $\beta$-sheet which are able to move relative to each other, permitting the entry of any substrate into the active site, other members of the Tritirachium serine proteinase gene family can be expected to show similarly broad substrate specificity. Of the 27 subsite-defining residues in the $C$. albicans SAP, there are only 11 differences between Sap1-Sap6, of which four might alter the enzyme's conformation (Cutfield et al., 1995). Furthermore, the experimental evidence suggests that there are no major differences in specificity amongst Sap1-Sap3 (Smolenski et al., 1997) in spite of the presence of three residues which might cause differences in the conformation of the substrate-binding sites of these three isoenzymes. Of the 26 subsite-defining residues in the $R$. chinensis SAP (Suguna et al., 1987, 1992), there is only one difference between the two isoenzymes (a Val/Ile substitution at position 15). Although no three-dimensional structures are available for the $R$. niveus proteinases, their substrate-binding sites may be identified by analogy with those of the $R$. chinensis enzyme. There are only four possibly significant differences out of a total of six differences between the residues defining the extended substrate-binding site in this SAP family. These observations suggest that there are unlikely to be major differences in specificity between the different isoenzymes of either the $R$. chinensis or the $R$. niveus SAP family. No sequence data are available for the $R$. oryzae enzymes.

In $R$. oryzae, C. albicans and T. album, these secreted proteinases probably function in providing a nitrogen supply for the organism when inorganic nitrogen in the environment is depleted (Farley \& Ikasari, 1992; Ross et al., 1990; Gunkel \& Gassen, 1989). Expression of the individual members of the Tritirachium gene family has not been examined, but the individual members of the Candida SAP gene family are known to be differentially regulated. Sap1-Sap3 are secreted by the yeast form of C. albicans, whereas Sap4-Sap6 are expressed by the hyphal form of the organism (Hube et al., 1994). The regulation of expression of individual sap genes has not be examined in any member of the genus Rhizopus. However, it is known that in $R$. oryzae, SAP activity is expressed under conditions of either nitrogen or sulphur derepression (Farley \& Ikasari, 1992).

The existence of these multigene families and the absence of significant differences in specificity amongst members of the family suggests that analysis of the expression of individual members of the family might contribute to understanding the significance of these multicopy genes. Since $R$. oryzae, unlike C. albicans, is not dimorphic and belongs to a different division of the fungal kingdom (the Zygomycota compared to the Ascomycota), as part of our interest in fungal secreted proteinase gene families we have examined how individual members of the sap gene family are regulated in $R$. oryzae.

\section{METHODS}

Strain, media and growth conditions. $R$. oryzae (CBS 515.94) used in this study was previously described as Rhizopus oligosporus USDB 0224 (Lim et al., 1987; Farley \& Ikasari, 1992) and was deposited in the Agricultural Research Service (ARS) culture collection as $R$. oligosporus (NRRL 22564).

Exponentially growing mycelium was harvested from submerged cultures incubated with shaking at $30^{\circ} \mathrm{C}$ for $12-14 \mathrm{~h}$ after inoculation with $10^{7}$ spores per $25 \mathrm{ml}$ minimal medium, which contained $55 \mathrm{mM}$ glucose, $50 \mathrm{mM} \mathrm{NH}_{4} \mathrm{Cl}, 11.2 \mathrm{mM}$ $\mathrm{KH}_{2} \mathrm{PO}_{4}, 7 \mathrm{mM} \mathrm{KCl}, 2 \cdot 1 \mathrm{mM} \mathrm{MgSO}$, and traces of ferrous and zinc chlorides. The mycelium was filtered, washed with treatment medium, transferred to fresh treatment medium and returned to the shaker (Farley \& Ikasari, 1992). Treatment media were obtained by modification of minimal medium as follows: nitrogen-free medium did not contain $\mathrm{NH}_{4} \mathrm{Cl}$; sulphur-free medium contained $\mathrm{MgCl}_{2}$ in place of $\mathrm{MgSO}_{4}$; medium containing protein as the sole nitrogen source was nitrogen-free medium containing BSA $(1 \%, \mathrm{w} / \mathrm{v})$; and medium containing protein as the sole sulphur source was sulphur-free medium containing BSA $(1 \%, w / v)$. The concentration of $\mathrm{KH}_{2} \mathrm{PO}_{4}$ was $33.6 \mathrm{mM}$ except in experiments where the $\mathrm{pH}$ of the medium was to be maintained in the range $\mathrm{pH} \mathrm{7-8}$, in which case $33.6 \mathrm{mM} \mathrm{K} \mathrm{KPO}_{4}$ was used instead of $\mathrm{KH}_{2} \mathrm{PO}_{4}$. For some experiments, as indicated in the text, the concentration of selected components of these treatment media was varied. The stock solution of BSA was $5.6 \%(\mathrm{w} / \mathrm{v})$, dialysed against at least five changes of distilled water and filter-sterilized $(0 \cdot 2 \mu \mathrm{m}$ filter $)$.

Primers and probes. Oligonucleotides were synthesized on an Applied Biosystems 380B synthesizer using $\beta$-cyanoethyl chemistry. Primers used for cDNA synthesis and in PCRs are indicated in Table 1. Oligonucleotide probes (also shown in Table 1) were radiolabelled using $\left[\gamma^{32} \mathrm{P}\right] \mathrm{dATP}$ and T4 polynucleotide kinase (United States Biochemical).

RNA isolation. Total RNA from $R$. oryzae was prepared using a modification of the guanidine hydrochloride procedure of Logemann et al. (1987). Unless indicated otherwise, all operations were carried out at room temperature. Mycelium was harvested by vacuum filtration, pressed between layers of filter paper to remove excess moisture and frozen in liquid nitrogen. Frozen mycelium was lyophilized (this step was essential for successful isolation of intact RNA) and the dry mycelium ground to a fine powder with a mortar and pestle. 
Table 1. Primer sequences and gene-specific oligonucleotide probes

\begin{tabular}{|ll|}
\hline Primer/probe name & \multicolumn{1}{c|}{ Sequence $\left(\mathbf{5}^{\prime} \mathbf{- 3}^{\prime}\right)$} \\
\hline Primers & \\
RSAPX1[sense] & CTTGA(T/C)TTTGA(T/C)AC(T/C)GG(T/C)TC \\
RSAPX2[sense] & A(A/G)TA(T/C)ATCTTTGGTGG(T/C)TATGA \\
RSAPX2[antisense] & TT(A/G)AAGACAACATAGTTGTTCTT \\
Adaptor primer & GGGGTACCGTCGACATCGA \\
Poly-T primer & GGGGTACCGTCGACATCGA(T) $)_{17}$ \\
RSAP3[sense] & GTACCACAATCGGTTCATCCAAG \\
RSAP3[antisense] & GGCAAAGTCATAATCACCATAACCA \\
RSAP4[sense] & CACGATCCCGGTCGATAACTCCAAT \\
RSAP4[antisense] & GTCACCATAACCGAAGCCAGCGATA \\
Probes & \\
sap1 & \\
sap2 & TGGTGGTCAAGTCACCACTAAACTTGGA \\
sap3 & CAAAGCTAGAGGTGTCACAGCTAATTGAA \\
sap4 & AGGGATTGTGGTCAAGGAACCGCTGTAT \\
rpys18 & TAGCACCATAGGCAGAGGCAACAGAGCG \\
universal sap probe & GAAGGTAGTCACGACGAACAACAAGAGT \\
\hline
\end{tabular}

The dry powder was added to the extraction buffer $18 \mathrm{M}$ guanidine hydrochloride, $20 \mathrm{mM}$ MOPS, $20 \mathrm{mM}$ EDTA, $50 \mathrm{mM} \beta$-mercaptoethanol at $\mathrm{pH} 7 \cdot 0$ ) at a ratio of $20 \mathrm{mg}$ dry mycelium: $1 \mathrm{ml}$ extraction buffer, mixed and centrifuged for $10 \mathrm{~min}$ at $16000 \mathrm{~g}$. The supernatant was extracted twice with an equal volume of phenol/chloroform/isoamyl alcohol (25:24:1, saturated in $0 \cdot 1 \mathrm{M}$ Tris/ $\mathrm{HCl}, \mathrm{pH} 8)$ and the RNA was precipitated at $-20^{\circ} \mathrm{C}$ overnight by the addition of 0.7 vol. ethanol and 0.2 vol. $1 \mathrm{M}$ acetic acid. The RNA was pelleted $(10 \mathrm{~min}$ at $9500 \mathrm{~g})$ and washed twice with $3 \mathrm{M}$ sodium acetate, pH $5 \cdot 5$, followed by $70 \%(\mathrm{v} / \mathrm{v})$ ethanol. The RNA pellet was dissolved in a small volume of water by incubation at $65^{\circ} \mathrm{C}$ for $5 \mathrm{~min}$ and the undissolved material was removed by centrifugation at $16000 \mathrm{~g}$ for $5 \mathrm{~min}$.

cDNA synthesis. cDNA used as template in PCR was prepared using the $M-M L V$ reverse transcriptase. In experiments to amplify the sap transcript, total RNA prepared from mycelium incubated in nitrogen-free medium for $4 \mathrm{~h}$ at $30^{\circ} \mathrm{C}$, was treated with proteinase $\mathrm{K}$ and DNase prior to $\mathrm{CDNA}$ synthesis using the degenerate RSAPX2[antisense] primer. cDNA for the amplification of the rpys 18 transcript was prepared from total RNA, isolated from mycelium incubated in minimal medium containing uric acid $(2 \mathrm{mM})$ as sole source of nitrogen, using the poly- $T$ primer.

DNA isolation. Medium containing $2 \%(\mathrm{w} / \mathrm{v})$ glucose, $0.3 \%$ yeast extract and $1 \%(\mathrm{w} / \mathrm{v})$ peptone was inoculated with $R$. oryzae spores $\left(10^{7}\right.$ spores per $25 \mathrm{ml}$ medium) and incubated with shaking at $30^{\circ} \mathrm{C}$ for $20 \mathrm{~h}$. The mycelium was harvested, washed with distilled water, pressed dry and frozen in liquid nitrogen. The frozen mycelium was freeze-dried, ground to a fine powder and stored at $-80^{\circ} \mathrm{C}$ until required. DNA was extracted from the ground mycelium by a modification of the method of Irelan et al. (1993). The dry powdered mycelium was suspended in $50 \mathrm{mM}$ Tris/ $\mathrm{HCl}, \mathrm{pH} 8$, containing $250 \mathrm{mM}$ EDTA and $2.5 \%(\mathrm{w} / \mathrm{v}) \mathrm{N}$-lauroylsarcosine and incubated at $65^{\circ} \mathrm{C}$ for 5-7 min. The high concentration of EDTA was required to inhibit fungal nucleolytic activity (Haas et al., 1990). Ammonium acetate was added, cell debris was removed and the DNA was precipitated with 2-propanol. The DNA was dissolved in $50 \mathrm{mM}$ Tris $/ \mathrm{HCl}, \mathrm{pH} 8$, containing $250 \mathrm{mM}$
EDTA and $1 \mathrm{mg}$ proteinase $\mathrm{K} \mathrm{ml}^{-1}$ (preincubated at $37^{\circ} \mathrm{C}$ for $15 \mathrm{~min}$ ) at $50^{\circ} \mathrm{C}$ and incubated at this temperature for a further $10 \mathrm{~min}$. Following chloroform/isoamyl alcohol extraction the DNA was incubated with RNase $A$ at $50^{\circ} \mathrm{C}$ for $10 \mathrm{~min}$. The chloroform/isoamyl alcohol extraction was repeated and the DNA was precipitated sequentially with ethanol $(2.5 \mathrm{M}$ ammonium acetate and 3 vols ethanol), followed by PEG (1 M NaCl and $8.2 \%, w / v, P E G)$ and finally with ethanol $(0 \cdot 1 \mathrm{M} \mathrm{NaCl}$ and 2 vols ethanol) to remove polyphosphates, as described by Rodriguez (1993). The final ethanol precipitation step was repeated once and the DNA was dissolved in $10 \mathrm{mM}$ Tris $/ \mathrm{HCl}, \mathrm{pH} 8$, containing $1 \mathrm{mM}$ EDTA.

PCR and analysis of products. sap cDNA was amplified using Taq DNA polymerase in $20 \mathrm{mM}$ Tris $/ \mathrm{HCl}, \mathrm{pH} 8 \cdot 4$, containing $50 \mathrm{mM} \mathrm{KCl}, 2.5 \mathrm{mM} \mathrm{MgCl}, 200 \mu \mathrm{M}$ each of dATP, dCTP, dGTP and dTTP and $6.65 \mu \mathrm{M}$ each of the RSAPX1[sense] and RSAPX2[antisense] primers. Thirty-two cycles of $30 \mathrm{~s}$ at $94^{\circ} \mathrm{C}, 30 \mathrm{~s}$ at $56^{\circ} \mathrm{C}$ and $30 \mathrm{~s}$ at $72{ }^{\circ} \mathrm{C}$ were performed, followed by $5 \mathrm{~min}$ at $72^{\circ} \mathrm{C}$ in a Corbett Research FTS-320 thermal sequencer. Products of the reaction were cloned in a T-vector prepared from EcoRV-cut pBluescript II $\mathrm{KS}(+)$. Clones were screened for those containing insert and randomly selected insert-containing clones were sequenced using an $\mathrm{ABI}$ $373 \mathrm{~A}$ automated sequencer and standard $\mathrm{ABI}$ protocols.

sap genomic DNA (11 $\mathrm{ng} \mathrm{\mu l}^{-1}$ final concentration) was amplified using the Expand High Fidelity system (Boehringer Mannheim) and an FTS-320 thermal sequencer (Corbett Research). PCR products were cloned in the T-vector and colonies were transferred to Hybond-N+ membranes. These were hybridized with radiolabelled probe, prepared by random-primed labelling (Feinberg \& Vogelstein, 1983) of the cloned sap1 and sap2 gene fragments (899 bp SalI-XbaI fragment), at $60^{\circ} \mathrm{C}$ overnight. Membranes were washed with $2 \times$ SSC, $0.5 \%$ SDS followed by $2 \times$ SSC, $0.1 \%$ SDS at room temperature for $5 \mathrm{~min}$ each and then $2 \times \mathrm{SSC}, 0.5 \% \mathrm{SDS}$ at $60^{\circ} \mathrm{C}$ for $2 \mathrm{~h}$ (medium stringency). This was followed by a higher stringency wash of $0.1 \times \mathrm{SSC}, 0.5 \%$ SDS at $65^{\circ} \mathrm{C}$ for $2 \mathrm{~h}$. Membranes were exposed at $-70^{\circ} \mathrm{C}$ to X-ray film and selected clones were sequenced. 
rpys18 cDNA was amplified using Taq DNA polymerase in $10 \mathrm{mM}$ Tris $/ \mathrm{HCl}$, pH 8.3, containing $50 \mathrm{mM} \mathrm{KCl}, 1.5 \mathrm{mM}$ $\mathrm{MgCl}_{2}, 200 \mu \mathrm{M}$ each of dATP, dCTP, dGTP and dTTP, and $0.75 \mu \mathrm{M}$ adaptor primer. Five cycles of $30 \mathrm{~s}$ at $94^{\circ} \mathrm{C}, 30 \mathrm{~s}$ at $45^{\circ} \mathrm{C}$ and $30 \mathrm{~s}$ at $72{ }^{\circ} \mathrm{C}$ were performed followed by 35 cycles of $30 \mathrm{~s}$ at $94^{\circ} \mathrm{C}, 30 \mathrm{~s}$ at $50^{\circ} \mathrm{C}$ and $30 \mathrm{~s}$ at $72^{\circ} \mathrm{C}$ and finally $5 \mathrm{~min}$ at $72^{\circ} \mathrm{C}$ in a FTS-320 thermal sequencer (Corbett Research). Products of the reaction were cloned in the $\mathrm{T}$ vector and randomly selected insert-containing clones were sequenced.

For the analysis of sap3 and sap4 expression, cDNA was amplified using Taq DNA polymerase in $10 \mathrm{mM}$ Tris $/ \mathrm{HCl}$, pH 9.0, containing $50 \mathrm{mM} \mathrm{KCl}$, and $0.1 \%$ Triton X-100, $3.0 \mathrm{mM} \mathrm{MgCl}, 200 \mu \mathrm{M}$ each of dATP, dCTP, dGTP and dTTP, and $1.0 \mu \mathrm{M}$ each of either the RSAP3[sense] and RSAP3[antisense] or the RSAP4[sense] and RSAP4[antisense] primers in a MJ Research PTC-200 thermal cycler. For amplification of the sap3 cDNA, 30 cycles of $5 \mathrm{~s}$ at $94^{\circ} \mathrm{C}$ and $35 \mathrm{~s}$ at $69^{\circ} \mathrm{C}$ were performed followed by $5 \mathrm{~min}$ at $72^{\circ} \mathrm{C}$. For amplification of the sap4 cDNA, 30 cycles of $5 \mathrm{~s}$ at $94^{\circ} \mathrm{C}$ and $30 \mathrm{~s}$ at $76^{\circ} \mathrm{C}$ were performed followed by $5 \mathrm{~min}$ at $72^{\circ} \mathrm{C}$.

Northern blotting, hybridization and autoradiography. For Northern blot analysis, $30 \mu \mathrm{g}$ total RNA was separated on formaldehyde-agarose gels (Sambrook et al., 1989), transferred to Hybond-N+ membranes (Amersham) using $10 \times \mathrm{SSC}$ and fixed in $50 \mathrm{mM} \mathrm{NaOH}$ for $5 \mathrm{~min}$. The membrane was washed in $2 \times$ SSC and air-dried. A preliminary gel was run to check RNA loadings; when necessary, the amount of sample used was adjusted to obtain approximately equal amounts of RNA in each lane of the gel. A 0.24-9.5 kb RNA ladder (Gibco-BRL Life Technologies) was used for size determinations. Membranes were prehybridized in Church buffer (Church \& Gilbert, 1984) at $40^{\circ} \mathrm{C}$ for $1 \mathrm{~h}$ and then incubated with radiolabelled probe in fresh Church buffer for at least $16 \mathrm{~h}$. The membranes were washed at room temperature with $2 \times$ SSC, $0.5 \%$ SDS and $2 \times$ SSC, $0.1 \%$ SDS and then at $42{ }^{\circ} \mathrm{C}$ with $0.1 \times$ SSC, $0.5 \%$ SDS for $2 \mathrm{~h}$. Membranes were exposed to X-ray film at $-70^{\circ} \mathrm{C}$. Because the mRNAs of the three sap genes which were expressed under the conditions studied were more or less the same size, separate membranes were prepared for the analysis of each member of the gene family.

Southern blotting, hybridization and autoradiography. For Southern analysis, $5 \mu \mathrm{g}$ EcoRI-digested DNA was separated on $0.8 \%$ agarose gels and transferred to Hybond-N+ membranes (Amersham) using $0.4 \mathrm{M} \mathrm{NaOH}$. The membrane was washed in $2 \times$ SSC and air-dried. HindIII-digested $\lambda$ DNA (Gibco-BRL Life Technologies) was used for size determinations. Membranes were prehybridized in Church buffer (Church \& Gilbert, 1984) at $60^{\circ} \mathrm{C}$ for $1 \mathrm{~h}$ and then hybridized with radiolabelled probe, prepared by random-primed labelling (Feinberg \& Vogelstein, 1983) of the cloned sap1 and sap2 gene fragments (899 bp SalI-XbaI fragment), at $60^{\circ} \mathrm{C}$ for at least $16 \mathrm{~h}$. Membranes were washed with $2 \times$ SSC, $0.5 \%$ SDS followed by $2 \times$ SSC, $0.1 \%$ SDS at room temperature for $5 \mathrm{~min}$ each and then $1 \times \mathrm{SSC}, 0.5 \%$ SDS at $65^{\circ} \mathrm{C}$ for $2 \mathrm{~h}$ (low stringency). This was followed by a higher stringency wash of $0.1 \times \mathrm{SSC}, 0.5 \%$ SDS at $65^{\circ} \mathrm{C}$ for $2 \mathrm{~h}$. Membranes were exposed to $\mathrm{X}$-ray film at $-70^{\circ} \mathrm{C}$.

Computer programs. Editing, analysis and alignment of sequences were carried out using the $A B I$ SeqEd program (version 1.0.3), ESEE (version 1.09d) (Cabot, 1989) and FASTA and BLAST from the Genetics Computer Group (Wisconsin sequence analysis package, version 8 ). Autoradiograms were scanned with a Bio-Rad GS-670 Imaging Densitometer and the digital images were processed with Molecular Analyst (version 2.1) and Adobe Photoshop (version 3.0.4) or NIH Image (version 1.60).

\section{RESULTS AND DISCUSSION}

\section{Identification of the $R$. oryzae sap gene family}

To obtain sequence data for individual members of the $R$. oryzae sap gene family, PCR was used to amplify part of the coding region of the gene. The sequence of the degenerate primers used was based on the sequences of the $R$. niveus gene family (Horiuchi et al., 1988; GenBank accession nos: M19100, X56964, X56965, X56992 and X56993) and the single sequence available for R. chinensis (Delaney et al., 1987; GenBank accession no. L33859). For two of the $R$. niveus sequences (X56964 and X56993) the location of the intron, as recorded in the GenBank annotation, is inconsistent with published data (Ashikari et al., 1990) and its use results in a coding sequence which, when translated, bears no resemblance to the sequence of aspartic proteinases except for the $\mathrm{N}$-terminal region. The position of the intron in these two sequences was therefore determined on the basis of published data on exon-intron boundaries in $R$. niveus (Ashikari et al., 1990). In each case the amino acid sequence, deduced from the coding sequence so obtained, was consistent with that of an aspartic proteinase. Three degenerate primers (RSAPX1[sense], RSAPX2[sense] and RSAPX2[antisense]) were designed based on the nucleotide sequences (Fig. 1).

In the first instance, because $R$. oryzae SAP is known to be secreted by mycelium incubated in nitrogen-free medium (Farley \& Ikasari, 1992), the PCR was performed using cDNA, prepared using RNA isolated from mycelium incubated for $4 \mathrm{~h}$ in nitrogen-free medium, and the RSAPX1[sense] and RSAPX2[antisense] primers, which were designed to amplify an $842 \mathrm{bp}$ fragment of the sap gene (Fig. 1). The PCR products, which on agarose gel electrophoresis ran as a single band of the expected size, were cloned and three independent clones were sequenced. These provided sequence data for two members of the gene family. That we obtained sequence data from two different transcripts was not unexpected given that, in $R$. chinensis, the SAP activity

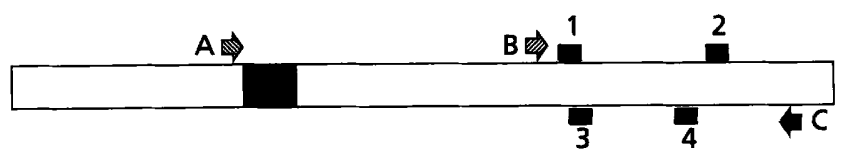

Fig. 1. ORFs of Rhizopus sap genes. The ORFs of the $R$. niveus sap genes are about 1200 nt and consist of two exons (about 330 and $845 \mathrm{nt}$ ) separated by a short intron (about 50-80 nt). A sap ORF is represented here by the rectangle, with the exons shown in white and the intron in black. The locations of primers used in the PCR are shown by arrows (arrow A, RSAPX1[sense]; arrow B, RSAPX2 [sense]; arrow C, RSAPX2 [antisense]) The location of the gene-specific probes are shown, by bars (1, sap1; 2, sap2; 3, sap3; 4, sap4). 
comprises two major isoenzymes. However, the sequence data available for $R$. niveus suggested that there might possibly be three additional members to this gene family. Southern analysis was performed using EcoRIdigested genomic DNA and PCR-derived fragments of the two genes ( $842 \mathrm{bp}$ ) as probes. EcoRI was chosen because it did not cleave either of the cloned gene fragments. At high stringency, the individual probes hybridized as single bands $(2.7 \mathrm{~kb}$ and $7.9 \mathrm{~kb})$. At lower stringency, additional bands $(3.5 \mathrm{~kb}$ and $4.7 \mathrm{~kb})$ were detected, suggesting that another member(s) of the gene family remained to be cloned.

To avoid missing members of the gene family which might not be expressed under conditions of nitrogen derepression and to simplify the search, the PCR was repeated using genomic DNA as template and the RSAPX2[sense] and RSAPX2[antisense] primers to amplify a $433 \mathrm{bp}$ fragment from the $3^{\prime}$ end of the gene (Fig. 1). Again, the products of the reaction were cloned and 336 clones were screened for other members of the gene family using a mixture of the two cloned genes as a probe. Clones which hybridized strongly at medium stringency but not at high stringency (a total of 106 clones) were identified as possible additional members of the gene family. Randomly selected clones from this subset were sequenced; a third member of the family was identified and used as a probe to narrow the search further. A fourth gene was found in addition to those already identified. In addition, the sequence of the two genes cloned from the first PCR was confirmed for the region of overlap. The four genes are referred to as sap1, sap2, sap3 and sap4. These four genes accounted for all the clones identified as possible members of the gene family in the first round of screening. However, during the process of screening these 106 clones it was observed that another 45 clones, which had not hybridized strongly to the combined probe during the first round of screening, hybridized at high stringency to the probes used in the third or fourth rounds of screening. Such variability leaves open the possibility that $R$. oryzae possesses an additional gene(s) which has not yet been identified.

All four sequences contained uninterrupted ORFs in the predicted orientation and the deduced amino acid sequences were $70-100 \%$ identical to those of the corresponding regions of the $R$. niveus sap gene products. Furthermore, all but two of the 169 invariant residues in the corresponding region of the $R$. niveus gene family were also invariable in the $R$. oryzae gene family. This is strong evidence that the sequences are those of the SAPs. The single intron present in the $R$. niveus genes lies $5^{\prime}$ of the 433 bp region amplified from $R$. oryzae genomic DNA, so the absence of any intron within the sequence was not unexpected. Within the $R$. oryzae gene family itself there was $77-87 \%$ identity at the nucleotide level and 76-92\% identity at the amino acid level between the four members of the gene family. This level of identity is comparable to that seen in $R$. niveus $(71-83 \%$ at the nucleotide level and $69-91 \%$ at the amino acid level, over the same region) but not to

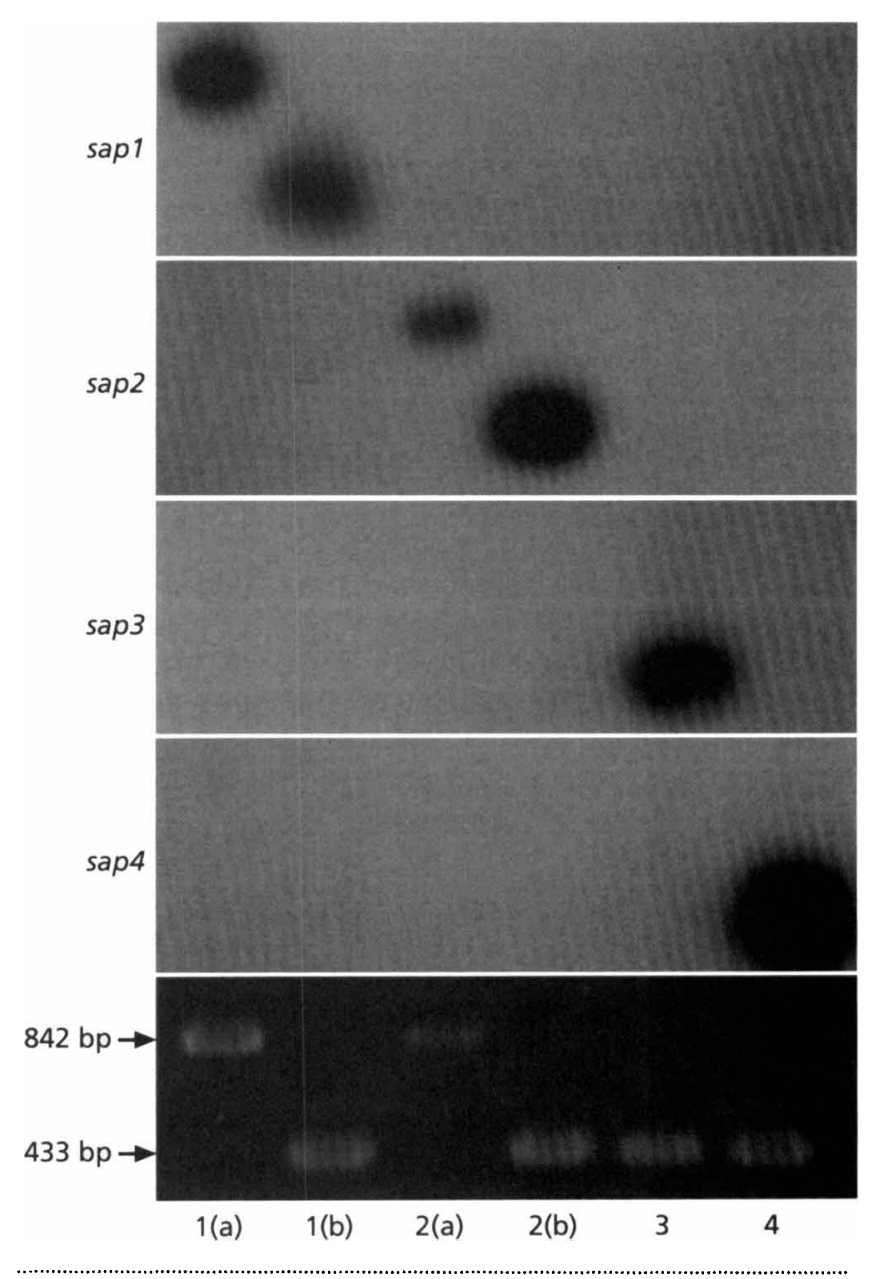

Fig. 2. Specificity of the oligonucleotide probes. Plasmids containing the cloned sap gene fragments (842 or $433 \mathrm{bp}$ ) were digested with Sall and Xbal. The DNA fragments were separated by agarose gel electrophoresis and transferred to Hybond- $\mathrm{N}+$ membranes. Membranes were hybridized with radiolabelled oligonucleotide probes as shown, washed at room temperature with $2 \times$ SSC, $0.5 \%$ SDS and $2 \times$ SSC, $0.1 \%$ SDS and then at $45^{\circ} \mathrm{C}$ with $0.1 \times$ SSC, $0.5 \%$ SDS for $2 \mathrm{~h}$. Lanes: $1(a, b)$, cloned sap1 gene fragments; $2(a, b)$, cloned sap2 gene fragments; 3 , cloned sap3 gene fragment; 4 , cloned sap4 gene fragment. The bottom panel shows the corresponding part of an ethidium bromide stained gel.

that seen in C. albicans (28-94\% at the amino acid level, over the same region). The C. albicans family, however, appears to consist of three groups and within these groups the level of identity is comparable to that seen in both Rhizopus species.

\section{Selection of probes and quantification of RNA}

Random-primed labelling of the cloned gene fragments produced probes which did not discriminate between the members of the gene family. An oligonucleotide probe was therefore designed for each gene (Fig. 1) and shown, in preliminary experiments using Southern blots of the cloned gene fragments, to be specific for that member of the gene family (Fig. 2). In addition, a 
degenerate oligonucleotide probe (hereafter referred to as the 'universal sap probe') was designed which hybridized to all four genes.

Two $R$. oryzae genes have been cloned: the glucoamylase gene (Ashikari et al., 1986) and the fumarase gene (Friedberg et al., 1995). In addition, sequence for part of the $R$. oryzae arginine-specific carbamyolphosphate synthetase gene (cpsa) was available (unpublished data; GenBank accession number AF025850). Nothing is known about expression of the glucoamylase gene. Transcription of the fumarase gene is increased under conditions of nitrogen limitation (Friedberg et al., 1995) whereas transcription of the cpsa gene is decreased about fivefold in mycelium incubated in either medium containing arginine as the sole nitrogen source or minimal medium containing BSA, compared to mycelium incubated in nitrogen-free medium (not shown). Neither were suitable controls for Northern analysis of sap expression. Instead, mRNA levels were measured relative to the rRNAs by loading approximately equal amounts of total RNA in each lane of the gel (Chambers \& Sullivan, 1993).

During the course of this work the $3^{\prime}$ region of an $R$. oryzae ribosomal protein gene, homologous to the yeast S18 and mammalian S11 genes, was fortuitously amplified by the PCR and cloned. An oligonucleotide probe based on this sequence (referred to as the rpys18 probe) was used as a positive control with all membranes analysed. Fungal ribosomal-protein mRNA levels are known to respond to carbon or nitrogen limitation (Vierula, 1997; Griffioen et al., 1996) and a similar response was observed in $R$. oryzae (not shown). Hybridization of the rpys 18 probe was therefore used to demonstrate that intact mRNA was present in samples which showed little or no hybridization to sap gene probes.

\section{Sizing of the rRNAs and sap transcripts}

Most fungal small subunit rRNA molecules, including those of the 11 Zygomycetes which have been studied, are between 1701 and $1853 \mathrm{nt}$ (van de Peer et al., 1997). The lengths of the large subunit rRNA from nine species of fungi, including two Zygomycetes, have been determined and they range in size from 3327 to $3484 \mathrm{nt}$ (de Rijk et al., 1997). The sizes of the $R$. oryzae small subunit and large subunit rRNA molecules, estimated from denaturing gel electrophoresis, were $1800 \mathrm{nt}$ and $3400 \mathrm{nt}$, respectively, both of which are within the range of sizes reported for other fungi.

sap4 transcripts were not detected on Northern blots under any of the conditions examined in this study. Membranes which failed to hybridize to the sap4 probe did hybridize to the rpys 18 probe $(0.76 \mathrm{~kb}$ transcript $)$ and to a probe for the $R$. oryzae cpsa gene $(1.7 \mathrm{~kb}$ transcript). The transcripts of the other three sap genes were all about $1.4 \mathrm{~kb}$, which is consistent with the expected size of the coding sequence $(1 \cdot 2 \mathrm{~kb})$ and falls within the range of transcript sizes seen for other fungal proteinase genes having a similar length of coding sequence (Clark et al., 1997; Hube et al., 1994; Jarai \& Buxton, 1994).

\section{pH regulation of sap expression}

The effect of the $\mathrm{pH}$ of the medium on sap expression was examined by Northern analysis of RNA extracted from mycelium incubated in medium designed to either allow the $\mathrm{pH}$ of the medium to fall from an initial value of about $\mathrm{pH} 5$ to a final value in the range $\mathrm{pH} 3-4$, or maintain the $\mathrm{pH}$ of the medium in the range $\mathrm{pH} 7-8$ (Fig. 3). sap transcripts were present in mycelium incubated in nitrogen-free medium, sulphur-free medium and medium containing BSA as the sole nitrogen source, and medium containing BSA as the sole sulphur source provided the $\mathrm{pH}$ of the medium was allowed to fall below pH 4.5 (Fig. 3, lanes 3-6). However, when the $\mathrm{pH}$ of the medium was prevented from falling below $\mathrm{pH}$ 7.0 no sap transcripts were detected (Fig. 3, lanes 9-12). The ribosomal protein gene transcript was present regardless of the $\mathrm{pH}$ of the medium, demonstrating that intact mRNA was present in the samples obtained from the high-pH media. On an overexposed autoradiograph (not shown), sap transcripts were also detectable in the RNA extracted from mycelium incubated in minimal medium or in minimal medium containing BSA but only when the $\mathrm{pH}$ of the medium was allowed to fall below $\mathrm{pH} 4.5$.

Taken together, the following two observations show that sap expression is regulated by the $\mathrm{pH}$ of the medium per se: (1) provided the $\mathrm{pH}$ of the medium is less than $\mathrm{pH} 4.5$, sap transcripts are present even in minimal medium and (2) under conditions in which sap transcripts are abundant even in the absence of exogenous protein, high $\mathrm{pH}$ turns off sap expression. A similar result was obtained for the $A$. niger $p e p A$ and $p e p B$ genes (Jarai \& Buxton, 1994), whereas the C. albicans SAP4-SAP6 genes were only expressed when the $\mathrm{pH}$ of the medium was pH 6 or higher (Hube et al., 1994). Proteins involved in modulating gene expression in response to the $\mathrm{pH}$ of the environment have been described in A. niger (Tilburn et al., 1995; MacCabe et al., 1996) and Saccharomyces cerevisiae (Li \& Mitchell, 1997). Similar proteins may be responsible for the $\mathrm{pH}$ dependent regulation of sap expression in $R$. oryzae. Expression of the C. albicans SAP2 gene is also affected by the $\mathrm{pH}$ of the medium, but in this case it is suggested that the effect is indirect in that the $\mathrm{pH}$ of the medium affects the rate at which exogenous protein is hydrolysed to produce peptides which induce $S A P 2$ expression (Hube et al., 1994).

Identical results were obtained using either the universal sap probe or a combination of the four gene-specific sap probes. Furthermore, the ratio of the amount of sap transcript relative to rRNA for the mycelium incubated in nitrogen-free medium to the amount of sap transcript relative to rRNA for the mycelium incubated in medium containing protein as the sole source of nitrogen was $1: 2$ for both the universal probe and the combination of the four gene-specific probes, which suggests that the $s a p$ 

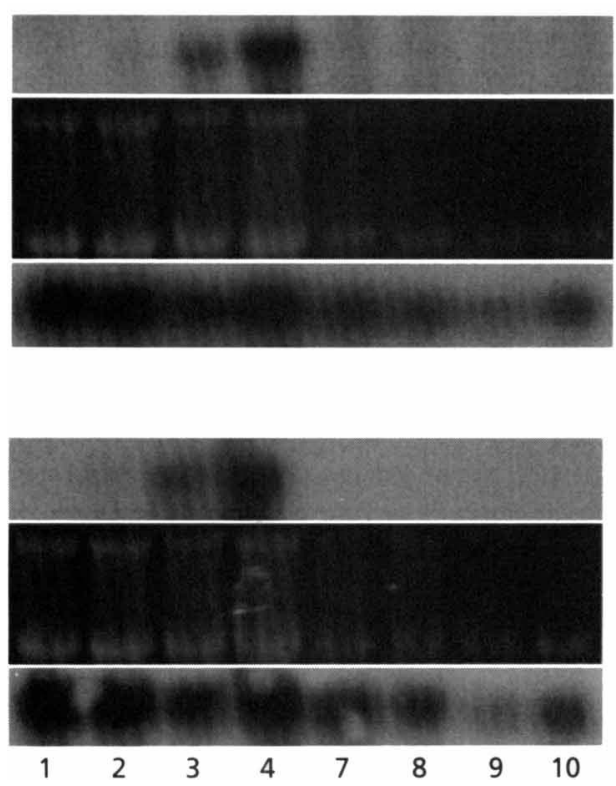

Universal sap probe

rRNA

rpys18 probe

Combined gene-specific probes

rRNA

rpys18 probe
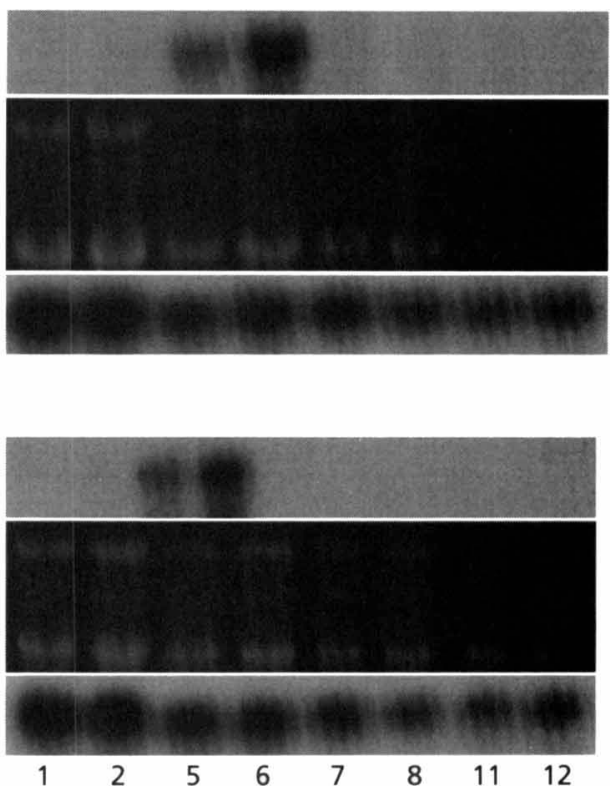

Fig. 3. $\mathrm{pH}$ regulation of sap gene expression. Mycelium was grown in minimal medium, transferred to treatment medium and incubated with shaking at $28^{\circ} \mathrm{C}$ for $5 \mathrm{~h}$. Total RNA was extracted and equal amounts $(30 \mu \mathrm{g})$ were subjected to denaturing gel electrophoresis. The lanes show RNA samples extracted from mycelium incubated in various media. Lanes: 1, minimal medium at low pH; 2, minimal medium containing BSA at low pH; 3, nitrogen-free medium at low pH; 4, medium containing BSA as the sole nitrogen source at low $\mathrm{pH} ; 5$, sulphur-free medium at low $\mathrm{pH} ; 6$, medium containing $\mathrm{BSA}$ as the sole sulphur source at low $\mathrm{pH} ; 7$, minimal medium at high $\mathrm{pH} ; 8$, minimal medium containing $\mathrm{BSA}$ at high $\mathrm{pH}$; 9, nitrogen-free medium at high $\mathrm{pH}$; 10 , medium containing $\mathrm{BSA}$ as the sole nitrogen source at high $\mathrm{pH}$; 11, sulphur-free medium at high $\mathrm{pH} ; 12$, medium containing BSA as the sole sulphur source at high $\mathrm{pH}$. Northern blots were hybridized with radiolabelled oligonucleotide probes as indicated.

sap1

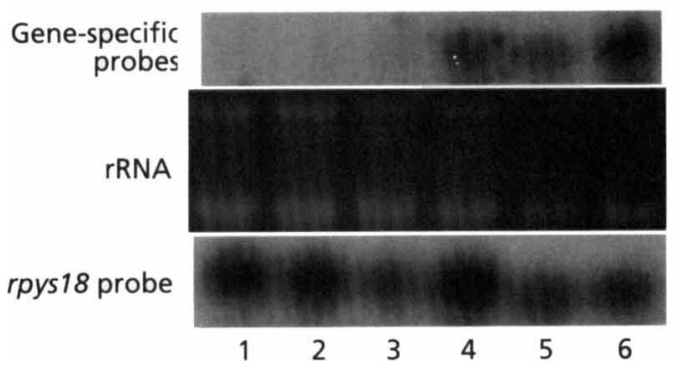

sap2

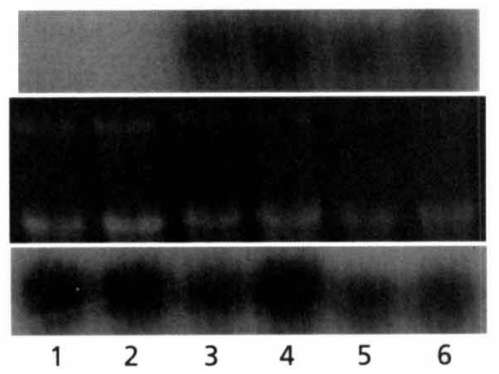

sap3

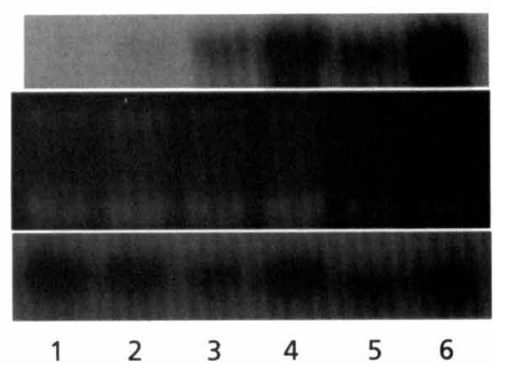

Fig. 4. Northern blot analysis of sap1, sap2 and sap3 expression in low-pH medium. Northern blots were prepared as described in the legend to Fig. 3 and probed with radiolabelled gene-specific oligonucleotides as shown. The lanes show RNA samples extracted from mycelium incubated in various media. Lanes: 1, minimal medium; 2 , minimal medium containing BSA; 3, nitrogen-free medium; 4, medium containing BSA as the sole source of nitrogen; 5 , sulphur-free medium; 6 , medium containing BSA as the sole source of sulphur. The rpys 18 probe hybridized to all the RNA samples.

genes identified in this study account for all the sap transcript detectable under these conditions. A similar result was obtained with the mycelium incubated in sulphur-free medium and medium which contained protein as the sole source of sulphur.

\section{Expression of the individual sap genes}

Northern analysis using the individual gene-specific probes showed that at low $\mathrm{pH}$ expression of sap1, sap2 and sap3 was repressed by the presence of inorganic nitrogen and sulphur in the medium, whereas all three genes were expressed in mycelium incubated under conditions of nitrogen or sulphur derepression. No sap1 or sap2 transcript was detected in mycelium incubated in minimal medium and the sap3 transcript was only detectable on an overexposed autoradiograph (Fig. 4, lane 1). All three transcripts are easily detectable in mycelium incubated in sulphur-free medium (Fig. 4, lane 5) and all three are present in mycelium incubated in nitrogen-free medium, although there was only a low level of the sap1 transcript (Fig. 4, lane 3). This result is 
(a)

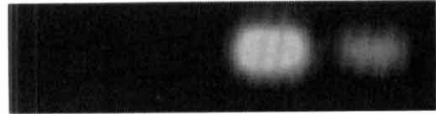

4

(b)

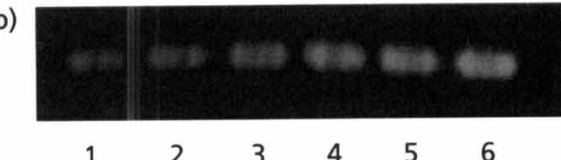

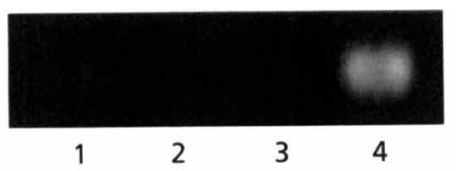

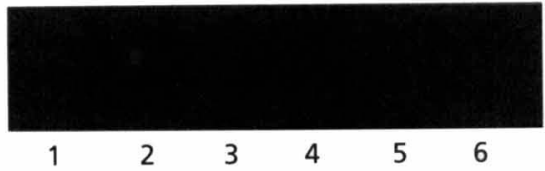

(2003)

Fig. 5. RT-PCR analysis of sap3 and sap4 expression in low-pH medium. (a) Specificity of the primers. The PCR was performed using the Sall-Xbal fragments described in Fig. 2 as template and either the RSAP3[sense] and RSAP3[antisense] primers (left-hand panel) or the RSAP4[sense] and RSAP4[antisense] primers (right-hand panel). Lanes: 1 , cloned sap1 gene fragment; 2 , cloned sap2 gene fragment; 3 , cloned sap3 gene fragment; 4 , cloned sap4 gene fragment. (b) RNA $(3 \mu \mathrm{g})$, prepared as described in the legend to Fig. 3, was treated with DNase and used for CDNA synthesis with the RSAPX2[antisense] primer. One twenty-fifth of the CDNA synthesis reaction was used as template for the PCR with either the RSAP3[sense] and RSAP3[antisense] primers (left-hand panel) or the RSAP4[sense] and RSAP4[antisense] primers (right-hand panel). A longer exposure of the right-hand panel is also shown below, but the faint band present in lane 6 (right-hand panel) is not visible in the photograph. The lanes show RNA samples extracted from mycelium incubated in various media. Lanes: 1 , minimal medium; 2 , minimal medium containing BSA; 3 , nitrogenfree medium; 4, medium containing BSA as the sole source of nitrogen; 5 , sulphur-free medium; 6 , medium containing BSA as the sole source of sulphur.

consistent with previous measurements of SAP activity (Farley \& Ikasari, 1992) and establishes that at low pH either nitrogen or sulphur derepression is sufficient to turn on expression of these three sap genes.

Farley \& Ikasari (1992) observed that the level of SAP activity after $5 \mathrm{~h}$ incubation in treatment medium was almost the same for nitrogen-free and sulphur-free medium, even though secretion of SAP activity in sulphur-free medium begins about $2 \mathrm{~h}$ later than in nitrogen-free medium. The higher rate of accumulation of SAP activity in sulphur-free medium can be explained by the higher level of sap transcripts observed in mycelium incubated in sulphur-free medium compared to mycelium incubated in nitrogen-free medium (Fig. 4; fourfold higher for sap3 and seven- to ninefold higher for sap1 and sap2). In addition, that the sap3 transcript levels are increased fourfold whereas the sap1 and sap2 transcripts are increased ninefold and sevenfold, respectively, indicates that there are differences in the promoter regions of these members of the sap gene family.

Transcripts for all three sap genes were also detected with exogenous protein as the sole nitrogen or sulphur source (Fig. 4, lanes 4 and 6). However, consistent with previous measurements of SAP activity (Farley \& Ikasari, 1992) which showed negligible levels of proteinase activity in minimal medium containing BSA, exogenous BSA alone was not sufficient to turn on expression of these genes to any significant extent. The sap2 transcript was not detected in mycelium incubated in minimal medium containing BSA (Fig. 4, lane 2) and the sap1 and sap 3 transcripts were only detected on an overexposed autoradiograph. Expression of the sap1, sap2 and sap 3 genes is, therefore, controlled at the level of transcription in a hierarchical manner in which $\mathrm{pH}$ occupies the higher position and the second level in the hierarchy is nitrogen or sulphur derepression. At both levels of control, sap1, sap2 and sap3 are co-ordinately controlled, i.e., the signals which turn on or off expression of any one of these genes turn on or off all three of them. From these experiments, however, it is not possible to determine the relative proportion of each sap gene transcript in the total pool of sap gene transcripts. A similar hierarchy of transcriptional control of expression of the $A$. niger pepA and $p e p B$ genes has been described by Jarai \& Buxton (1994).

sap4 transcripts were not detected on Northern blots but analysis, following Li et al. (1981), of the number of nucleotide substitutions per site at each position of the codons in the partial sequence of sap4 compared to that for the other three sap genes did not provide any evidence that sap4 was a pseudogene. RT-PCR was used to determine whether or not any sap4 transcript was present in mycelium incubated at low $\mathrm{pH}$ at levels below the detection limit of Northern analysis (Fig. 5). sap3 transcripts were also analysed to provide a positive control. Under the conditions used for the PCR, the primers for amplification of the sap 4 cDNA were completely specific for sap4 (Fig. 5a). The primers for amplification of the sap3 cDNA also amplified sap4; however, the amplification of sap4 was less efficient and Northern analysis had shown that under derepression conditions the level of any sap4 transcripts would be insignificant in comparison to the level of sap3 transcripts. The relative yields of the sap3 and sap4 PCR 
products were consistent with the results of the Northern analysis, which had shown that sap4 transcripts were less abundant than sap3 transcripts. The yields of PCR products for $s a p 3$ (Fig. $5 \mathrm{~b}$ ) were also consistent with the pattern of sap3 expression determined by Northern analysis, in that the sap3 transcript had been shown to be present in all the samples analysed and levels of the sap3 transcript were higher under derepressed than repressed conditions. sap 4 transcripts were present in mycelium under all the conditions examined, as evidenced by the presence of product of the expected size in the PCR. However, there was less PCR product and therefore less sap4 transcript present in the samples from mycelium incubated under conditions of nitrogen or sulphur derepression (fourfold and eightfold less product, respectively) than in mycelium incubated in minimal medium (Fig. 5b, right-hand panel; compare lanes 1, 3 and 5). The pattern of expression of sap4 is in contrast to that of sap1, sap2 and sap3, which suggests that there are major differences in the promoter region of the sap 4 gene compared to those of the other three members of the sap gene family.

\section{Role of exogenous protein in sap expression}

Under nitrogen or sulphur derepression conditions, the addition of exogenous BSA to the medium increases the amount of sap transcript relative to rRNA levels in the mycelium (Fig. 4; compare lanes 4 and 6 with lanes 3 and 5). Similar results were obtained for A. niger (Jarai $\&$ Buxton, 1994). The ratio of the amount of sap transcript relative to the rRNA for mycelium incubated in nitrogen-free medium, to the amount of sap transcript relative to the rRNA for the mycelium incubated in medium containing protein as the sole nitrogen source, is $1: 13$ for sap1 and 1:5 for both sap2 and sap3. Similarly, for sulphur-free medium and medium containing protein as the sole sulphur source, the ratio is $1: 1$ for sap2 and 1:2 for both sap1 and sap3. It might be expected that the amount of SAP activity in the medium would increase as a consequence of the higher levels of sap transcripts, but this is not the case. The amount of SAP activity relative to the mass of mycelium present in the medium is either the same (nitrogen derepression conditions) or reduced (sulphur derepression conditions) (Farley \& Ikasari, 1992). It is possible, therefore, that in addition to transcriptional activation of sap gene expression under derepression conditions, translation of the sap transcript and/or secretion of SAP protein is regulated, or autodegradation of the secreted enzyme is occurring.

The addition of exogenous protein to these derepression media may, however, be having a more general metabolic effect rather than a specific effect on sap gene expression. In particular, addition of exogenous protein to the medium may have metabolic consequences other than direct induction of sap gene expression. The effect of exogenous BSA on sap expression under sulphur derepression conditions can be mimicked (and even exceeded) by the addition of glucose to the medium, equivalent, on a molar basis, to the amino acids available

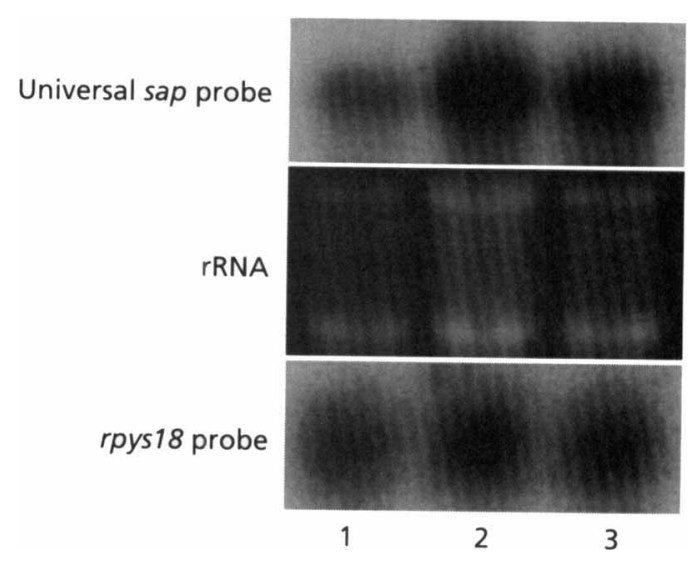

Fig. 6. Northern analysis of sap expression on various sulphur derepression media. A Northern blot was prepared as described in the legend to Fig. 3 and probed with radiolabelled probes as shown. The lanes show RNA samples extracted from mycelium incubated in various media. Lanes: 1 , sulphur-free medium containing $55 \mathrm{mM}$ glucose; 2, sulphur-free medium containing $171 \mathrm{mM}$ glucose; 3 , medium containing $55 \mathrm{mM}$ glucose and $1 \%$ (w/v) BSA as the sole source of sulphur. The rpys18 probe hybridized to all three RNA samples.

\section{Universal sap probe}

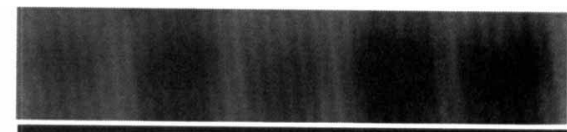

rRNA

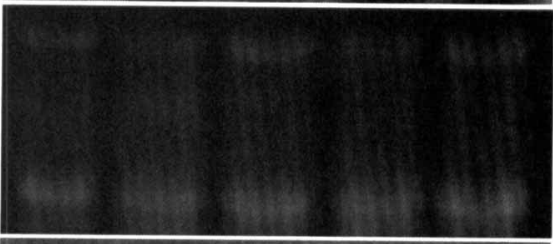

rpys18 probe

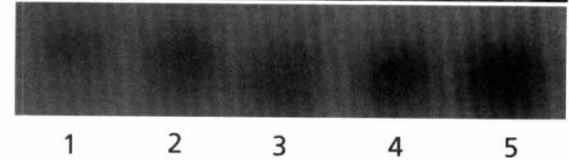

Fig. 7. Northern analysis of sap expression on various nitrogen derepression media. A Northern blot was prepared as described in the legend to Fig. 3 and probed with radiolabelled probes as shown. The lanes show RNA samples extracted from mycelium incubated in various media. Lanes: 1 , nitrogen-free medium containing $55 \mathrm{mM}$ glucose; 2 , medium containing $55 \mathrm{mM}$ glucose, and $0.1 \mathrm{mM}$ glycine, $0.2 \mathrm{mM}$ aspartate and $0.3 \mathrm{mM}$ glutamine as the sole sources of nitrogen; 3 , nitrogen-free medium containing $171 \mathrm{mM}$ glucose; 4 , medium containing $171 \mathrm{mM}$ glucose, and $0.1 \mathrm{mM}$ glycine, $0.2 \mathrm{mM}$ aspartate and $0.3 \mathrm{mM}$ glutamine as the sole sources of nitrogen; 5 , medium containing $55 \mathrm{mM}$ glucose and $1 \%(\mathrm{w} / \mathrm{v})$ BSA as the sole source of nitrogen. The rpys18 probe hybridized to all five RNA samples.

from hydrolysis of the BSA (Fig. 6). Under nitrogen derepression conditions, glucose is without effect, but the effect of exogenous BSA on sap expression under these conditions can be mimicked by the addition of aspartate, glycine and glutamine in amounts equivalent to, or less than, those provided by hydrolysis of the BSA (Fig. 7). These results suggest that exogenous protein 
might affect the level of sap transcripts indirectly by the provision of metabolic intermediates, which might be substrates for energy production or precursors in the synthesis of nucleotides, rather than directly by induction of sap gene expression.

\section{Functional significance of the sap gene family}

A number of reasons for the existence of gene families within a particular organism have been suggested. These include the provision of duplicates of essential genes to provide a safety net for the cell, the provision of an array of enzymes having slightly different specificities, the provision of enzymes which can be independently regulated under different environmental or physiological conditions and the provision of multiple copies of a gene to achieve a higher level of expression of the gene product than would be possible from a single copy of the gene.

SAPs would not appear to be essential for growth of $R$. oryzae, since the fungus is able to utilize a range of alternative nitrogen sources such as ammonium salts, urea, uric acid and xanthine. Since there is $69-76 \%$ identity between the amino acid sequences of the proteinases from $R$. oryzae and $R$. chinensis, the substrate-binding sites of the $R$. oryzae enzymes may be identified by analogy with those of the $R$. chinensis enzymes. The sequence data obtained in this study provides information on all but two residues (positions 15 and $16 ; R$. chinensis numbering) defining the substrate-binding site in SAP1 and SAP2 and for 11 of the 26 subsite-defining residues in SAP3 and SAP4. There are four differences amongst the $R$. oryzae isoenzymes (positions 222, 225, 278 and 294), of which two may be significant (the Phe/Tyr substitution at position 278 and the Asp/Tyr substitution at position 294). However, since similar differences between the $C$. albicans isoenzymes have no effect on substrate specificity (Cutfield et al., 1995; Smolenski et al., 1997), the differences observed for the $R$. oryzae isoenzymes are unlikely to result in significant differences in specificity between these isoenzymes. This is a common feature of all known fungal proteinase gene families.

sap1, sap2 and sap3 are co-ordinately expressed at low $\mathrm{pH}$ under conditions of either nitrogen or sulphur derepression. sap4 is independently regulated, but represents only a minor fraction of the total pool of sap transcript under all the conditions examined in this study. The presence of three genes (sap1, sap2 and sap3) encoding proteinases with almost identical substratebinding sites and, by implication, specificity, which are all expressed under identical conditions, suggests that these genes exist to provide amplified sap expression under conditions of low $\mathrm{pH}$ and nitrogen or sulphur derepression.

Long-term survival of the fungus in the absence of its preferred nitrogen source (ammonium salts), which may be the most abundant nitrogen source available only in laboratory media, is dependent on the fungus finding a secondary nitrogen supply. In this situation, $R$. oryzae responds by the production of catabolic enzymes involved in two different nitrogen-assimilation pathways [protein assimilation (Farley \& Ikasari, 1992) and purine assimilation (P. C. Farley \& S. Santosa, unpublished)]. Attempts to induce nitrite reductase activity under these conditions have been unsuccessful (A. U. Dewi, A. S. Krave \& P. C. Farley, unpublished), suggesting that $R$. oryzae, like $R$. oligosporus (Sorenson \& Hesseltine, 1966), is unable to utilize nitrate as a secondary nitrogen source. That overall expression of the sap genes (protein assimilation pathway) is amplified by turning on multiple copies of the gene suggests that protein is a particularly important secondary nitrogen source for this fungus and reflects how much protein needs to be degraded to obtain sufficient nitrogen for growth (about $6 \times 10^{20}$ peptide bonds have to be hydrolysed to provide $1 \mathrm{mmol}$ nitrogen from protein). This may be the case, not only in $R$. oryzae, but also in the other fungi which amplify expression of a secreted proteinase by turning on multiple members of a gene family.

In the case of $R$. oryzae, which has been used for centuries in the fermentation of soya beans to produce tempe, protein would be the main nitrogen source available to the fungus during this fermentation. The turning on and amplification of sap gene expression, together with the existence and expression of enzymes involved in purine but not nitrate assimilation, fits perfectly with its use in the tempe fermentation, whether this is a consequence of centuries of selection for these traits or part of the reason for it being suitable for this fermentation process in the first place.

\section{REFERENCES}

Ashikari, T., Nakamura, N., Tanaka, Y., Kiuchi, N., Shibano, Y., Tanaka, T., Amachi, T. \& Yoshizumi, H. (1986). Rhizopus rawstarch-degrading glucoamylase: its cloning and expression in yeast. Agric Biol Chem 50, 957-964.

Ashikari, T., Amachi, T., Yoshizumi, H., Horiuchi, H., Takagi, M. \& Yano, K. (1990). Correct splicing of modified introns of a Rhizopus proteinase gene in Saccharomyces cerevisiae. Mol Gen Genet 223, 11-16.

Barrett, A. J. (1994). Classification of peptidases. Methods Enzymol 244, 1-15.

Berka, R. M., Ward, M., Wilson, L. J., Hayenga, K. J., Kodama, K. H., Carlomagno, L. P. \& Thompson, S. A. (1990). Molecular cloning and deletion of the gene encoding aspergillopepsin A from Aspergillus awamori. Gene 86, 153-162.

Berka, R. M., Carmona, C. L., Hayenga, K. J., Thompson, S. A. \& Ward, M. (1993). Isolation and characterization of the Aspergillus oryzae gene encoding aspergillopepsin O. Gene 125, 195-198.

Betzel, C., Pal, G. P. \& Saenger, W. (1988). Three-dimensional structure of proteinase $\mathrm{K}$ at $0 \cdot 15 \mathrm{-nm}$ resolution. Eur J Biochem 178, 155-171.

Betzel, C., Singh, T. P., Visanji, M., Peters, K., Fittkau, S., Saenger, W. \& Wilson, K. S. (1993). Structure of the complex of proteinase $K$ with a substrate analogue hexapeptide inhibitor at $2 \cdot 2 \AA$ resolution. J Biol Chem 268, 15854-15858.

Bouchara, J.-P., Oumeziane, N. A., Lissitzky, J.-C., Larcher, G., Tronchin, G. \& Chabasse, D. (1996). Attachment of spores of the 
human pathogenic fungus Rhizopus oryzae to the extracellular matrix components. Eur J Cell Biol 70, 76-83.

Cabot, E. (1989). A sequence editor for microcomputer users. Trends Biochem Sci 14, 14.

Chambers, R. S. \& Sullivan, P. A. (1993). Expression of the exoglucanase gene in yeast and hyphal forms of Candida albicans. FEMS Microbiol Lett 111, 63-68.

Church, G. M. \& Gilbert, W. (1984). Genomic sequencing. Proc Natl Acad Sci USA 81, 1991-1995.

Clark, S. J., Templeton, M. D. \& Sullivan, P. A. (1997). A secreted aspartic proteinase from Glomerella cingulata: purification of the enzyme and molecular cloning of the cDNA. Microbiology 143, 1395-1403.

Cutfield, S. M., Dodson, E. J., Anderson, B. F., Moody, P. C. E., Marshall, C. J., Sullivan, P. A. \& Cutfield, J. F. (1995). The crystal structure of a major secreted aspartic proteinase from Candida albicans in complexes with two inhibitors. Structure 3, 12611271.

Delaney, R., Wong, R. N. S., Meng, G., Wu, N. \& Tang, J. (1987). Amino acid sequence of rhizopuspepsin isozyme pl5. J Biol Chem 262, 1461-1467.

Espinel-Ingroff, A., Oakley, L. A. \& Kerkering, T. M. (1987). Opportunistic zygomycotic infections. Mycopathologia 97, 3341.

Fallon, K., Bausch, K., Nooran, J., Huguenel, E. \& Tamburini, P. (1997). Role of aspartic proteases in disseminated Candida albicans infection in mice. Infect Immun 65, 551-556.

Farley, P. C. \& Ikasari, L. (1992). Regulation of the secretion of Rhizopus oligosporus extracellular carboxyl proteinase. J Gen Microbiol 138, 2539-2544.

Feinberg, A. P. \& Vogelstein, B. (1983). A technique for radiolabelling DNA restriction endonuclease fragments to high specific activity. Anal Biochem 132, 6-13.

Friedberg, D., Peleg, Y., Monsonego, A., Maissi, S., Battat, E., Rokem, J. S. \& Goldberg, I. (1995). The fumR gene encoding fumarase in the filamentous fungus Rbizopus oryzae: cloning, structure and expression. Gene 163, 139-144.

Frye, C. B. \& Reinhardt, D. J. (1993). Characterization of groups of the zygomycete genus Rhizopus. Mycopathologia 124, 139-147.

Griffioen, G., Laan, R. J., Mager, W. H. \& Planta, R. J. (1996). Ribosomal protein gene transcription in Saccharomyces cerevisiae shows a biphasic response to nutritional changes. Microbiology 142, 2279-2287.

Gunkel, F. A. \& Gassen, H. G. (1989). Proteinase K from Tritirachium album Limber. Eur J Biochem 179, 185-194.

Haas, M. J., Genvario, R. \& Feairheller, S. H. (1990). Construction of a Rhizopus delemar genomic library and screening for direct lipase gene expression. Food Biotechnol 4, 647-661.

Horiuchi, H., Yanai, K., Okazaki, T., Takagi, M. \& Yano, K. (1988). Isolation and sequencing of a genomic clone encoding aspartic proteinase of Rhizopus niveus. J Bacteriol 170, 272-278.

Hube, B., Monod, M., Schofield, D. A., Brown, A. J. P. \& Gow, N. A. R. (1994). Expression of seven members of the gene family encoding secretory aspartyl proteinases in Candida albicans. Mol Microbiol 14, 87-99.

Irelan, J., Miao, V. \& Selker, E. U. (1993). Small scale DNA preps for Neurospora crassa. Fungal Genet Newsl 40, 24.

Jarai, G. \& Buxton, F. P. (1994). Nitrogen, carbon and $\mathrm{pH}$ regulation of extracellular acidic proteases of Aspergillus niger. Curr Genet 26, 238-244.

Jarai, G., Kirchherr, D. \& Buxton, F. P. (1994). Cloning and characterization of the pepD gene of Aspergillus niger which codes for a subtilisin-like protease. Gene 139, 51-57.

Li, W. \& Mitchell, A. P. (1997). Proteolytic activation of Rim1p, a positive regulator of yeast sporulation and invasive growth. Genetics 145, 63-73.

Li, W.-H., Gojobori, T. \& Nei, M. (1981). Pseudogenes as a paradigm of neutral evolution. Nature 292, 237-239.

Lim, G., Tan, T. K. \& Rahim, N. A. (1987). Variations in amylase and protease activities among Rhizopus isolates. MIRCEN J Appl Microbiol Biotechnol 3, 319-322.

Logemann, J., Schell, J. \& Willmitzer, L. (1987). Improved method for the isolation of RNA from plant tissues. Anal Biochem 163, 16-20.

Longacre, A., Reimers, J. M., Gannon, J. E. \& Wright, B. E. (1997). Flux analysis of glucose metabolism in Rbizopus oryzae for the purpose of increasing lactate yields. Fungal Genet Biol 21, 30-39.

MacCabe, A. P., van den Hombergh, J. P. T. W., Tilburn, J., Arst, H. N. \& Visser, J. (1996). Identification, cloning and analysis of the Aspergillus niger gene $p a c C$, a wide domain regulatory gene responsive to ambient $\mathrm{pH}$. Mol Gen Genet 250, 367-374.

Monod, M., Togni, G., Hube, B. \& Sanglard, D. (1994). Multiplicity of genes encoding secreted aspartic proteinases in Candida species. Mol Microbiol 13, 357-368.

Nout, M. J. R. \& Rombouts, F. M. (1990). Recent developments in tempe research. J Appl Bacteriol 69, 609-633.

Ohtsuru, M., Tang, J. \& Delaney, R. (1982). Purification and characterization of rhizopuspepsin isoenzymes from a liquid culture of Rhizopus chinensis. Int J Biochem 14, 925-932.

van de Peer, Y., Jansen, J., de Rijk, P. \& de Wachter, R. (1997). Database on the structure of small ribosomal subunit RNA. Nucleic Acids Res 24, 111-116.

Radford, A., Stone, P. J. \& Taleb, F. (1996). Cellulase and amylase complexes. In The Mycota. IIl. Biochemistry and Molecular Biology, pp. 269-294. Edited by R. Brambl \& G. A. Marzluf. Berlin: Springer.

de Rijk, P., van de Peer, Y. \& de Wachter, R. (1997). Database on the structure of large ribosomal subunit RNA. Nucleic Acids Res 24, 117-123.

Rodriguez, R. J. (1993). Polyphosphate present in DNA preparations from filamentous fungal species of Colletotrichum inhibits restriction endonucleases and other enzymes. Anal Biochem 209, 291-297.

Ross, I. K., De Bernardis, F., Emerson, G. W., Cassone, A. \& Sullivan, P. A. (1990). The secreted aspartate proteinase of Candida albicans: physiology of secretion and virulence of a proteinase-deficient mutant. J Gen Microbiol 136, 687-694.

Sakaguchi, K., Tagaki, M., Horiuchi, H. \& Gomi, K. (1992). Fungal enzymes used in oriental food and beverage industries. In Applied Molecular Genetics of Filamentous Fungi, pp. 54-99. Edited by J. R. Kinghorn \& G. Turner. Glasgow: Blackie.

Samai, B. B., Karan, B., Boone, T. C., Chen, K. K., Rohde, M. F. \& Stabinsky, Y. (1989). Cloning and expression of the gene encoding a novel proteinase from Tritirachium album Limber. Gene 85, 329-333.

Samai, B. B., Karen, B., Boone, T. C., Osslund, T. D., Chen, K. K. \& Stabinsky, Y. (1990). Isolation and characterization of the gene encoding a novel, thermostable serine proteinase from the mould Tritirachium album Limber. Mol Microbiol 4, 1789-1792.

Sambrook, J., Fritsch, E. F. \& Maniatis, T. (1989). Molecular Cloning: a Laboratory Manual, 2nd edn. Cold Spring Harbor, NY: Cold Spring Harbor Laboratory. 
Smolenski, G., Sullivan, P. A., Cutfield, S. M. \& Cutfield, J. F. (1997). Analysis of secreted aspartic proteinases from Candida albicans: purification and characterization of individual Sap1, Sap2 and Sap3 isoenzymes. Microbiology 143, 349-356.

Sorenson, W. G. \& Hesseltine, C. W. (1966). Carbon and nitrogen utilization by Rhizopus oligosporus. Mycologia 58, 681-689.

Suguna, K., Bott, R. R., Padlan, E. A., Subramanian, E., Sheriffs, S., Cohen, G. H. \& Davies, D. R. (1987). Structure and refinement at $1.8 \AA$ resolution of the aspartic proteinase from Rhizopus chinensis. J Mol Biol 196, 877-900.

Suguna, K., Padlan, E. A., Bott, R., Boger, J., Parris, K. D. \& Davies, D. R. (1992). Structures of complexes of rhizopuspepsin with pepstatin and other statine-containing inhibitors. Proteins Struct Funct Genet 13, 195-205.

Takahashi, K. (1988). Determination of the amino acid sequences of the two major isoenzymes of rhizopuspepsin. J Biochem 103, 162-167.
Tilburn, J., Sarkar, S., Widdick, D. A., Espeso, E. A., Orejas, M., Mungroo, J., Penalva, M. A. \& Arst, H. N. (1995). The Aspergillus $\mathrm{PacC}$ zinc finger transcription factor mediates regulation of both acid- and alkaline-expressed genes by ambient $\mathrm{pH}$. EMBO J 14, 779-790.

Vierula, P. J. (1997). Cloning and characterization of a Neurospora crassa ribosomal protein gene, crps-7. Curr Genet 31, 139-143.

Wang, H. L. \& Hesseltine, C. W. (1965). Studies on the extracellular proteolytic enzymes of Rhizopus oligosporus. Can $J$ Microbiol 11, 727-732.

Webster, J. (1980). Introduction to Fungi, 2nd edn, p. 213. Cambridge: Cambridge University Press.

Received 5 January 1998; revised 31 March 1998; accepted 20 April 1998. 